\title{
PENGARUH TEMAN SEBAYA TERHADAP KECENDERUNGAN BULLYING PADA SD PADAMU NEGERI MEDAN
}

\author{
Reflina Sinaga \\ Surel: sinagareflina@yahoo.co.id
}

\begin{abstract}
ABSTRAK
Penelitian ini bertujuan untuk mengetahui dan memahami pengaruh positif teman sebaya terhadap kecenderungan perilaku bullying pada siswa SD serta pengaruh negatif teman sebaya terhadap kecenderungan perilaku bullying pada siswa SD. Hasil analisis data menggunakan rumus regresi sederhana diperoleh nilai koefisien determinasi ( $\mathrm{R}$ square) sebesar 0,726 atau $72,6 \%$ yang berarti $72,6 \%$ perilaku bullying siswa dipengaruhi oleh teman sebaya. Berdasarkan analisis data, maka dapat diketahui bahwa $\mathrm{F}$ hitung sebesar 121,871 dengan tingkat signifikan 0,000. Oleh karena probabilitas $(0,000)$ jauh lebih kecil dari 0,05 (dalam kasus ini menggunakan taraf signifikansi atau $\alpha=5 \%$ ), maka model regresi bisa dipakai untuk memprediksi perilaku bullying. Dengan pedoman Jika sig < 0,05 dan t-hitung $\geq \mathrm{t}$-tabel maka $\mathrm{H}^{\mathrm{a}}$ diterima dan $\mathrm{H}^{\circ}$ ditolak.
\end{abstract}

Kata Kunci : Pengaruh Teman Sebaya, Perilaku, Bullying

\section{PENDAHULUAN}

Maraknya kasus-kasus

kekerasan yang terjadi pada anakanak usia sekolah saat ini sangat memprihatinkan bagi pendidik dan orangtua. Sekolah yang seharusnya menjadi tempat bagi anak menimba ilmu serta membantu membentuk karakter pribadi yang positif ternyata malah menjadi tempat tumbuh suburnya praktek-praktek bullying, sehingga memberikan ketakutan bagi anak untuk memasukinya

Beberapa faktor diyakini menjadi penyebab terjadinya perilaku bullying di sekolah, antara lain adalah faktor kepribadian, komunikasi interpersonal yang dibangun remaja dengan orangtuanya, peran kelompok teman sebaya dan iklim sekolah.
Berdasarkan penelitian yang dilakukan Sejiwa (2007) bahwa sebagian kecil guru (27,5\%) menganggap bullying merupakan perilaku normal dan sebagian besar guru $(73 \%)$ menganggap bullying sebagai perilaku yang membahayakan siswa. Hal tersebut tidak bisa dianggap normal karena siswa tidak dapat belajar apabila siswa berada dalam keadaan tertekan, terancam dan ada yang menindasnya setiap hari.

Kasus bullying di Indonesia seringkali terjadi di institusi pendidikan. Hal ini dibuktikan dengan data dari Komisi Nasional Perlindungan Anak, tahun 2011 menjadi tahun dengan tingkat kasus bullying tertinggi di lingkungan sekolah yaitu sebanyak 339 kasus 
kekerasan dan 82 diantaranya meninggal dunia (Komnas PA, 2011). Para ahli menyatakan bahwa school bullying merupakan bentuk agresivitas antarsiswa yang memiliki dampak paling negatif bagi korbannya. Perilaku bullying merupakan perilaku agresif yang serius. Perilaku agresif dapat terjadi karena berbagai faktor. Faktor-faktor situasional yang dapat memicu terbentuknya perilaku agresif menurut O'Connell (dalam Astuti, 2008) antara lain budaya sekolah (bullying yang dilakukan guru atau teman sebaya), teknologi dan norma kelompok.

Perilaku bullying adalah masalah sosial dan lingkungan sekolah merupakan salah satu faktor atas terjadinya perilaku tersebut pertama kali berspekulasi bahwa perilaku bullying/agresif yang dilakukan oleh para siswa merupakan sebuah reaksi dari rasa frustasi dan kegagalan di sekolah (Usman). Hal ini didukung oleh sebuah hasil penelitian yang dilakukan oleh Salwina dkk (2009) yang mengungkapkan bahwa ada hubungan yang signifikan antara rendahnya nilai prestasi belajar dengan perilaku bullying.

Penelitian ini bertujuan:

a. Untuk mengetahui dan memahami pengaruh positif teman sebaya terhadap kecenderungan perilaku bullying pada siswa SD. b. Untuk mengetahui dan memahami pengaruh negatif teman sebaya terhadap kecenderungan perilaku bullying pada siswa SD.

\section{METODE PENELITIAN}

Sebelum digunakan untuk mengumpulkan data, instrument diuji validitas dan reliabilitasnya. Untuk mengetahui validitas dan reliabilitas digunakan rumus Product Moment dengan bantuan progam SPSS 16 for Windows. Dari hasil uji validitas variabel teman sebaya terdapat 15 item valid. Sedangkan perhitungan validitas variabel perilaku bullying terdapat 15 item valid. Sedangkan reliabilitas menggunakan rumus alpha cronbach.

Variabel terikat penelitian ini adalah perilaku bullying dan variabel bebas adalah teman sebaya.

Dalam pengumpulan data penelitian ini dilakukan dengan menggunakan alat ukur skala psikologi.

Dalam analisa data menggunakan rumus Regresi sederhana dengan rumus sebagai berikut. Dengan norma keputusan sebagai berikut a. Jika sig $<0,05$ maka $\mathrm{H}^{\mathrm{a}}$ diterima dan $\mathrm{H}^{\circ}$ ditolak b. Jika sig > 0,05 maka $\mathrm{H}^{\mathrm{a}}$ ditolak dan $\mathrm{H}^{\circ}$ diterima.

\section{HASIL DAN PEMBAHASAN}

Hasil penelitian berdasarkan kategorisasi skor subjek pada skala 
kecenderungan perilaku bullying, dapat diketahui bahwa tidak ada responden yang memiliki perilaku bullying sangat tinggi. Dengan perincian adalah sebanyak 8 orang $(15,5 \%)$ memiliki perilaku bullying yang tinggi, 26 orang atau 50\% berperilaku bullying sedang, 14 orang atau $26,2 \%$ berperilaku bullying yang rendah dan sebanyak 2 orang atau 7.8\% memiliki perilaku bullying sangat rendah. Hasil ini menunjukkan bahwa siswa siswa SD Padamu Negeri Medan hanya memiliki perilaku bullying yang sedang saja.

Adapun hasil lengkap dari kategorisasi skor subjek pada skala perilaku bullying dapat dilihat pada tabel di bawah ini:

\begin{tabular}{|c|c|c|c|c|}
\hline Variabel & $\begin{array}{c}\text { Rentang } \\
\text { Nilai }\end{array}$ & Kategori & Jumlah & $\begin{array}{c}\text { Prosent } \\
\text { ase (\%) }\end{array}$ \\
\hline $\begin{array}{c}\text { Perilaku } \\
\text { bullying }\end{array}$ & $\mathrm{X}<19.2$ & $\begin{array}{c}\text { Sangat } \\
\text { Rendah }\end{array}$ & 2 & 7,8 \\
\cline { 2 - 5 } & $\begin{array}{c}19.2 \leq \mathrm{X} \\
<25.2\end{array}$ & Rendah & 14 & 26.2 \\
\cline { 2 - 5 } & $\begin{array}{c}25.2 \leq \mathrm{X} \\
<34.8\end{array}$ & Sedang & 26 & 50.5 \\
\cline { 2 - 5 } & $\begin{array}{c}34.8 \leq \mathrm{X} \\
<39.6\end{array}$ & Tinggi & 8 & 15.5 \\
\cline { 2 - 5 } & $\mathrm{X}>39.6$ & $\begin{array}{c}\text { Sangat } \\
\text { Tinggi }\end{array}$ & 0 & 0.0 \\
\cline { 2 - 5 } & Total & & 50 & 100 \\
\hline
\end{tabular}

\section{Kategorisasi Skor Subjek Pada Skala} Peran Kelompok Teman Sebaya

\begin{tabular}{|l|c|c|c|c|}
\hline Variabel & $\begin{array}{c}\text { Rentang } \\
\text { Nilai }\end{array}$ & Kategori & Jlh & $\begin{array}{c}\text { Prosentase } \\
(\%)\end{array}$ \\
\hline $\begin{array}{l}\text { Peran } \\
\text { kelomp } \\
\text { ok } \\
\text { teman } \\
\text { sebaya }\end{array}$ & $\mathrm{X}<24$ & $\begin{array}{c}\text { Sangat } \\
\text { Rendah }\end{array}$ & 2 & 3,9 \\
\cline { 2 - 5 } & $\begin{array}{c}31,5 \leq \\
\mathrm{X}<\end{array}$ & Rendah & 4 & 2,9 \\
\cline { 2 - 5 } & $\begin{array}{c}31.5 \\
\mathrm{X}<\end{array}$ & Sedang & 21 & 21,4 \\
& 43.5 & Tinggi & 13 & 35,0 \\
\cline { 2 - 5 } & $43.5 \leq$ & . & & \\
\hline
\end{tabular}

\begin{tabular}{|l|c|c|c|c|}
\hline & $\begin{array}{l}\mathrm{X}< \\
49.5\end{array}$ & & & \\
\cline { 2 - 5 } & $\mathrm{X}>$ \\
49.5 & Sangat & \multirow{2}{*}{10} & 36,9 \\
\cline { 2 - 5 } & Total & & 50 & 100 \\
\hline
\end{tabular}

Berdasarkan hasil kategorisasi di atas, dapat diketahui bahwa peran kelompok teman sebaya, terdapat 2 orang $(3,9 \%)$ dalam kategori sangat rendah, sebanyak 4 orang $(2,9 \%)$ yang berada dalam kategori rendah, kategori sedang sebanyak 21 orang $(21,4 \%), 13$ orang $(35,0 \%)$ dalam kategori tinggi, dan sebanyak 10 orang $(36,9 \%)$ dengan kategori yang sangat tinggi.

Dari hasil pengolahan data dengan menggunakan bantuan program SPSS for windows Versi 15, maka didapat kesimpulan analisis asumsi dari sub-struktur pertama, yaitu: uji normalitas dilakukan dengan menggunakan Kolmogorov Smirnov. Menurut Kerlinger (1990) variabel dikatakan terdistribusi normal apabila $p>0,05$. Berdasarkan data dari tabel di bawah dapat dilihat untuk variabel kecenderungan perilaku bullying diperoleh signifikansi sebesar 0,229 ( $p>0,05)$, ini menunjukkan bahwa populasi terdistribusi normal. Untuk variabel teman sebaya diperoleh signifikansi sebesar $0,126 \quad(\mathrm{p}>0,05)$, ini menunjukkan bahwa populasi terdistribusi normal.

Hasil analisis data dengan menggunakan rumus regresi sederhana diperoleh nilai koefisien determinasi ( $\mathrm{R}$ square) sebesar 0,726 atau $72,6 \%$ yang berarti $72,6 \%$ 
perilaku bullying siswa dipengaruhi oleh teman sebaya. Berdasarkan analisis data, maka dapat diketahui bahwa F hitung sebesar 121,871 dengan tingkat signifikan 0,000 . Oleh karena probabilitas $(0,000)$ jauh lebih kecil dari 0,05 (dalam kasus ini menggunakan taraf signifikansi atau $\alpha$ $=5 \%$ ), maka model regresi bisa dipakai untuk memprediksi perilaku bullying. Dengan pedoman Jika sig < 0,05 dan thitung $\geq \mathrm{t}$-tabel maka $\mathrm{H}^{\mathrm{a}}$ diterima dan $\mathrm{H}^{\circ}$ ditolak.

Berdasarkan hasil kategorisasi skor subjek pada skala perilaku bullying di atas, dapat diketahui bahwa sebanyak 8 orang $(15,5 \%)$ memiliki perilaku bullying yang tinggi, 26 orang atau $50 \%$ berperilaku bullying sedang, 14 orang atau $26,2 \%$ berperilaku bullying yang rendah dan sebanyak 2 orang atau $7.8 \%$ memiliki perilaku bullying sangat rendah. Hasil ini menunjukkan bahwa siswa SD Padamu Negeri Medan hanya memiliki perilaku bullying yang sedang saja. Namun perlu diperhatikan juga bahwa ada 8 orang atau $15,5 \%$ siswa yang melakukan perilaku bullying secara intens di sekolah. Hal ini tentu saja tidak dapat dibiarkan begitu saja, karena dikhawatirkan akan sangat mempengaruhi kondisi psikologis dari siswa yang menjadi korban dan hal ini menunjukkan bahwa masih ada siswa SD Padamu Negeri Medan yang melakukan bullying di sekolah. Hasil penelitian ketiga menemukan bahwa peran kelompok teman sebaya terbukti berpengaruh negatif terhadap perilaku bullying pada siswa SD Padamu Negeri Medan. Hasil penelitian ini sesuai dengan hasil penelitian Nation dkk (2007) yang menemukan bahwa perilaku bullying disebabkan oleh tekanan dari teman sebaya agar dapat diterima dalam kelompoknya. Kelompok teman sebaya adalah sekelompok teman yang mempunyai ikatan emosional yang kuat dan siswa dapat berinteraksi, bergaul, bertukar pikiran, dan pengalaman dalam memberikan perubahan dan pengembangan dalam kehidupan sosial dan pribadinya.

Berdasarkan kategorisasi skor siswa tentang peran kelompok teman sebaya menunjukkan bahwa peran kelompok teman sebaya berada pada kategori tinggi atau sebesar 35\% dan sangat tinggi atau sebesar 36,9\%. Hal ini menunjukkan bahwa tekanan dari kelompok teman sebaya pada siswa untuk melakukan perilaku bullying sangat rendah. Senada dengan hal tersebut, Eisenberg dan Aalsma (2005) mengungkapkan bahwa siswa SD Padamu Negeri Medan tidak tergantung lagi pada tekanan-tekan ataupun keputusan-keputusan dari teman sebayanya untuk melakukan perilaku bullying, karena pada SD Padamu Negeri Medan ini siswa sudah mampu berpikir secara objektif tentang apa yang harus dilakukannya dan meningkatnya nilai-nilai 
moralitas dalam dirinya. Hasil penelitian keempat menemukan bahwa iklim sekolah berpengaruh negatif dan signifikan terhadap perilaku bullying pada siswa SD Padamu Negeri Medan. Perilaku sering terjadi di sekolah, untuk itu seluruh elemen yang ada di sekolah secara bersama-sama menanggulangi tindakan bullying. Ada beberapa program yang telah dibuat oleh para ahli di bidang pendidikan dan psikologi untuk menanggulangi perilaku bullying di sekolah. Salah satu program anti bullying yang ditawarkan oleh para ahli adalah program SAHABAT yang dikembangkan oleh Astuti (2008). Program ini mengutamakan nilai-nilai etika yang mengandung nilai-nilai sosial dan kultural persahabatan. Elemen etika itu berupa "kasihSAyang, HArmoni, Baik-budi, bertAnggung jawab, dan persaTuan. Program SAHABAT melibatkan semua pihak yang berada di sekolah termasuk orangtua. Aktivitas tersebut dapat berupa support network, kampanye dan penelitian.

\section{DAFTAR RUJUKAN}

Adila, Nisa (2009). Pengaruh Kontrol Sosial Terhadap Perilaku Bullying Pelajar di Sekolah Menengah Pertama. Jurnal Kriminologi Indonesia, 5(1), 56-66.
Andina, E. (2014). Budaya Kekerasan Antar Anak di Sekolah Dasar. Jurnal Kesejahteraan, Vol. IV No. 09.

Arikunto, S. (2002). Prosedur Penelitian: Suatu Pendekatan Praktek. Jakarta: Rineka Cipta.

Bauman, S., \& Del Rio, A. 2005. Knowledge and Beliefs about Bullying in Schools: Comparing Pre-Service teachers in the United States and United Kingdom. Journal of School Psychology International, 26 (4): 428-442.

Bransford, J.D. 2003. The Best Years: Panduan Mendampingi Perkembangan Sosial dan Emosional Anak di Masa Remaja. (Alih Bahasa: Rica Hapsari; Editor: Tim Prestasi Pustakaraya). Jakarta: Penerbit Prestasi Pustakaraya.

Edwards, D. C. (2006). Ketika Anak Sulit Diatur: Perpaduan Bagi Orang Tua Untuk Mengubah Masalah Perilaku Anak. Bandung: Kaifa.

Lee, C. 2004. Preventing Bullying in School: A Guide for teachers and Other Profesionals. 
Reflina Sinaga: Pengaruh Teman Sebaya ...

London: Paul Chapman Publishing.

Ponny, R. Astuti. (2008). Meredam Bullying: 3 Cara Efektif Menanggulangi Kekerasan pada Anak. Jakarta: Grasindo.

SEJIWA (Yayasan Semai Jiwa Amini). (2008). Bullying: Mengatasi Kekerasan di Sekolah dan Lingkungan). Jakarta: Grasindo.

Triyuda, P. (2012). Komnas PA: Tahun 2011 Bullying di Sekolah 139 Kasus, Tahun Ini 36 Kasus. (Online). http://detikNews/KomnasPATahun-2011-BullyingSekolah139-Kasus,-Tahun- 13 Ini-36Kasus.htm. Diakses pada 14 Juni 2016.

Usman, Irvan (TT). Perilaku Bullying ditinjau dari Peran Kelompok Teman Sebaya dan Iklim Sekolah Pada Siswa SMA di Kota Gorontalo. Gorontalo: Fakultas Ilmu Pendidikan. Skripsi. Diakses dari http://libraryung.ac.id/ diunduh pada tanggal 20 Juni 2016 